\title{
Reciprocal Trade Agreements in Asia: Credible Commitment to Trade Liberalization or Paper Tigers?
}

\author{
Raymond Hicks and Soo Yeon Kim
}

\begin{abstract}
Reciprocal trade agreements (RTAs) have proliferated rapidly in Asia in recent years, an unprecedented phenomenon in a region in which state-led institution-building efforts were largely unsuccessful during the Cold War years. In this article, we investigate the qualitative provisions of RTAs in Asia, focusing on agreements that are professedly geared toward trade liberalization through reciprocal exchanges of trade concessions. We build on the concept of credible commitmentthat states "tie their hands" through international agreements and thus signal strong commitment to trade liberalization. We argue that a broad range of agreement provisions will affect an RTA's ability to achieve its primary objective: trade liberalization. We present a coding scheme that measures the strength of a wide variety of provisions in the legal texts of RTAs. Using quantitative analysis, we analyze the impact of various components of Asia's RTAs on participants' trade flows. KEYWORDS: trade agreements, Asia, trade, credible commitment
\end{abstract}

RECIPROCAL TRADE AGREEMENTS (RTAS) HAVE "PROLIFERATED" RAPIDLY IN Asia since the mid-1990s and especially in the aftermath of the Asian financial crisis. The dramatic rise in trade agreements is an unprecedented phenomenon for Asia, where state-led institution-building efforts were largely unsuccessful during the Cold War years. Through the mid-1990s, the region saw few RTAs in force, and the prevailing mode of trade cooperation involved the Asia-Pacific Economic Cooperation (APEC) forum formed in 1989 and the more regionally delimited Association of Southeast Asian Nations (ASEAN), which in 1992 announced its intention to form the ASEAN Free Trade Area (AFTA). ${ }^{1}$ The shift toward RTAs, especially bilateral trade agreements, represents a marked departure from previous trends (Ravenhill 2003, 2008a, 2008b). Earlier initiatives in trade governance consisted mainly of APEC's multilateralism and open regionalism, which involved concerted unilateral trade liberal- 
ization and the practice of most-favored nation (MFN) for members and nonmembers alike. ${ }^{2}$

The recent "rush" for RTAs in Asia, as unprecedented as it is for the region, is nevertheless consistent with the global trend of an ever expanding network of trade agreements outside the World Trade Organization (WTO). RTA formation has become an increasingly important part of economic integration in the region, and the "noodle bowl" configuration of RTA projects is a key component of the institutional architecture for economic cooperation that is emerging in the region, one that has seen the active participation of important trading nations such as China and India. The rapid spread of RTAs raises the question of whether these do indeed represent strong state commitments to trade liberalization or are "paper tigers" that are merely symbolic declarations. We engage this important question both theoretically and empirically. We identify the key components of trade liberalization that are encoded in the texts of RTAs and evaluate their success in actually expanding trade among participants.

In this article we analyze fifty-seven RTAs in Asia that were signed or were in effect as of $2006 .{ }^{3}$ The theoretical argument focuses on the qualitative aspects of RTAs - namely, the degree to which they constitute mechanisms of "credible commitment" by tying the hands of governments with respect to trade policy. RTAs, as do trade agreements more generally, resolve the prisoner's dilemma problem that is inherent to trade, thus producing cooperation that would be difficult absent such institutional obligations. We argue that RTAs differ widely in the quality of this "credible commitment." In doing so, we depart from the prevailing practice of relying on a dichotomous formulation: the presence or absence of an RTA. Instead, we present a nineteen-point coding scheme to code the quality of commitments in RTAs and develop a comprehensive index based on the coding scheme. The analysis tests the hypothesis that the stronger the institutional commitments of an RTA, the greater the expansion of trade between participant countries.

The empirical analysis finds strong support for the hypothesis that high-quality RTAs are more effective in boosting trade between agreement partners. The use of a continuous measure of RTA participation also identifies weaknesses in the dichotomous presence-absence formulation, which tends to overestimate the impact of RTAs on trade flows at low levels of credible commitment but underestimates this effect at high levels. Overall, we distinguish between those agreements that effectively bind their participants and boost trade from the paper tigers. We also identify, by examining agreement provisions, what may constitute a set of best practices for effectively bringing about trade liberalization through RTAs. 
We begin by providing the theoretical approach of the article. We then present our coding scheme, the comprehensive index, and a set of descriptive statistics on RTAs in Asia. The quantitative analysis employs a standard gravity model of international trade with fixed effects to evaluate the impact of trade agreements on trade flows. We provide empirical assessments of both the comprehensive index and its individual components.

\section{Trade Agreements: \\ Credible Commitment to Trade Liberalization}

Trade agreements are international institutions of credible commitment, enabling participants to commit to trade liberalization through institutional arrangements that tie their hands and constrain them "to obey a set of rules that do not permit leeway for violating commitments" (North and Weingast 1989, 804). Credible commitment resolves two key cooperation problems in trade. First, trade agreements are an important and effective mechanism for resolving the collaboration problem inherent in a liberal trading order, especially for large economies. In the classic formulation of this cooperation problem, governments, in formulating trade policy, have incentives to generate a terms-of-trade externality-that is, unilaterally protectionist policies to induce political support from domestic interest groups (Grossman and Helpman 1994, 1995) that improve the terms of trade for the national economy but are multilaterally costly as policy costs are shifted to trade partner countries (Bagwell and Staiger 2010). Trade agreements that provide for reciprocal (rather than onesided) trade liberalization allow governments to avoid such a terms-oftrade-driven prisoner's dilemma setting, and they are an effective means by which governments can adopt low tariffs that are also "efficient" in terms of coinciding with governmental preferences (Bagwell and Staiger 1999, 2002).

Trade agreements also resolve the time inconsistency problem whereby governments have incentives ex post to seek "beggar-thy-neighbor" policies that ex ante did not serve their objectives. Much in the way that an independent central bank ties the hands of government and constrains them from pursuing an expansionary monetary policy following a commitment to low inflation, a trade agreement is an external commitment device that ties the hands of a government vis-à-vis domestic interest group pressures and constrains it from adopting protectionist trade policy following signature (Maggi and Rodríguez-Clare 1998, 2007; see also Carmichael 1987; Staiger and Tabellini 1987; Matsuyama 1990; Brainard 1994; Mitra 2002). The trade liberalization provisions of the agreement, 
for example, specify institutionally mandated maximum trade barriers for certain products that insulate participant governments from domestic interest group pressures to increase protectionist measures beyond them once the agreement is in effect. Trade agreements, RTAs among them, thus provide an institutional mechanism for governments to signal credible commitment to trade liberalization.

While countries may institutionalize "credible commitment" to trade liberalization by signing on to RTAs, the degree of such commitment varies in important ways. In this article, we conceptualize credible commitment as a continuum that captures two main interrelated components: high costs of defection and substantive strength. A trade agreement demonstrates strong credible commitment when institutional arrangements make defection very costly through high levels of obligation that legally bind actors to their institutional commitments (Abbott et al. 2000, 17). Second, high levels of obligation must be matched by substantive strength in the range of actions to be governed by the agreement. One can imagine an agreement with high levels of obligation that strongly prevents an actor from reneging but in which the agreement imposes no meaningful constraints on actors' behavior and requires little action of any kind from the participants. Applied to trade agreements, an agreement that scores high on obligation but alters trade restrictions for only a limited group of products would not be an effective external commitment device, nor would an agreement that covers products in which the participant countries do not engage in extensive trade. Such agreements, even if they provided for strong legal obligation, would function as little more than a paper tiger, a largely symbolic gesture that would be ineffective in signaling credible commitment or in liberalizing trade.

\section{Coding Credible Commitment in RTAs}

We seek to capture the high costs of defection and substantive strength in RTAs by examining the legal provisions of the trade agreement, similar to the literature on central bank independence (Grilli, Masciandaro, and Tabellini 1991; Cukierman, Webb, and Neyapti 1994). In doing so, we differentiate RTA provisions across five major categories of provisions comprising nineteen individual components. Appendix 1 contains detailed information about the coding scheme.

Type of agreement. The closer the economic ties a trade agreement creates, the higher the level of credible commitment in the agreement, all else equal. That is, an economic union requires a higher level of credible commitment than a free trade area, so it will receive a higher score 
in this category. It is entirely possible, of course, that the trade agreement may propose a common market or an economic union but that the final objective is achieved so far in the future that it signals only weak commitment to trade liberalization. This type of symbolic commitment will be accounted for with components of the index in other categories. Thus we expect that RTAs that provide for the formation of economic unions will contribute more toward expanded trade flows than other types of trade agreements.

Breadth of coverage. The indicators in this category largely focus on the policy requirements the agreement imposes on the participant governments. ${ }^{4}$ A trade agreement will embody less credible commitment if it eliminates tariffs but allows the government to maintain other types of trade restrictions such as nontariff barriers or technical barriers to trade. Also, the broader the scope of coverage of the agreement, the higher the level of credible commitment. That is, an agreement that covers both agricultural and industrial products will tie the hands of the government vis-à-vis domestic interest groups more than one that excludes either of these sectors. By including politically sensitive areas such as agriculture, a government can more easily resist protectionist pressures from this sector.

Depth of coverage. Components of this category measure the level of obligation in an RTA and the stringency of enforcement mechanisms (Abbott et al. 2000). They indicate how much room for maneuver countries have and how formalized the interactions are between agreement partners. If matters like dispute settlement are treated more objectively, we expect the trade agreement to demonstrate a higher level of credible commitment; however, if there is not a mechanism for solving disputes or if injured parties can demand whatever compensatory damages they desire, the trade agreement will signal weak credible commitment, as each party may not trust the others to be fair. Also, the agreement should score lower on credible commitment the more easily it allows countries to take advantage of escape clauses, antidumping provisions, or other exclusions to limit trade liberalization.

The coding of escape clauses raises the idea of a tension between the level of obligation and flexibility in agreements. ${ }^{5}$ Logically, the credibility of escape clauses should run from the weakest with the "ability to invoke at any time," to a middle stage where there are "strict guidelines on invoking the escape clause," to the strongest where there is "no ability to invoke an escape clause." Scholars have argued, however, that flexibility mechanisms in institutional design are "optimal" in trade 
agreements, as they provide for institutional adaptation to changing circumstances in domestic trade politics (Rosendorff and Milner 2001; Maggi and Rodríguez-Clare 2007). Especially when conceptualizing reciprocal trade agreements as incomplete contracts, escape clause provisions are important in the negotiation of trade agreements, as their inclusion allows participant governments to retain discretion over trade policy in times of exogenous shocks or surges in imports.

While we agree that flexibility mechanisms such as escape clauses are important in reducing the contracting costs associated with negotiating a trade agreement, our interest lies, first, in the level of flexibility embodied in such provisions and, second, in how economic actors view the commitment reflected in agreement provisions following the signature of the agreement. This is because we focus on the impact of provisions in agreements that have been successfully negotiated and signed. We argue that once trade agreements are signed and proceed to the implementation stage, the balance between the level of obligation to trade liberalization and the flexibility of escape clauses function as powerful signals of credible commitment. The stringency of rules regarding the invocation of escape clauses, we argue, also contributes to signaling credible commitment vis-à-vis economic actors. We thus code flexibility provisions in trade agreements according to the logical order, giving agreements that contained provisions disallowing escape clauses the highest credible commitment score for this component.

The last component in this depth of coverage category captures provisions for formal institutions and regular meetings, which reflect higher levels of credible commitment because such institutional arrangements reduce transaction costs among its members and facilitate transparency. Rules that govern these trade agreements will be clearer and more objective, and disputes and other issues can be easily discussed in regularly convened meetings. In other words, formal institutions and regular meetings will make the actions taken in the name of the agreement more transparent, which enhances credible commitment. We hypothesize that trade agreements with provisions for greater depth of coverage will also be more effective in promoting trade liberalization.

Pace of change. This category measures the length of time stipulated to reach the final objective of the agreement and the magnitude of trade liberalization as the agreement goes into effect. An agreement that envisages meeting its final objective well into the future is less credible than one that will meet its objective in the short term. How should the full implementation of the agreement be measured? Some agreements are easy to code be- 
cause they specify a timetable for reaching the goal (e.g., "all tariffs will be eliminated by year 10"). Other agreements assign categories of reduction to different tariff lines so different products will have different timetables. One option would be to take the category with the longest timetable and say that the objective is not met until that timetable is reached.

We assume that governments will offer more protection to politically sensitive areas than to others. Governments will negotiate a longer implementation time for products in politically sensitive sectors, and we capture this important side of domestic trade politics by coding the timetable as the longest period of time until the agreement completes its objectives. However, if an agreement permanently excludes some products, these products are not considered in the timetable variable. We recognize that this coding may give too much emphasis to a couple of product lines but believe it is the best alternative available. We expect that the longer the time horizon for full implementation of the trade agreement, the less effective the agreement will be in liberalizing trade between its participants.

The second component indicates the extent of tariff reductions as the agreement goes into effect. Again, because different products have different tariff reduction schedules, this component is difficult to quantify. Some trade agreements list the extent of the tariff cuts in the agreement, while others list them as a schedule in an annex that is, unfortunately, not available for all trade agreements. As a compromise, we focused on the percentage of tariff lines in a country's schedule that would be duty-free when the agreement enters into force. To code this measure we examined the tariff schedules to determine how many of the lines would be reduced to 0 ; we also consulted news articles or government assessments of trade agreements that listed the proportion of tariff lines reduced to $0 .{ }^{6}$ The biggest problem with this measurement is that trade agreements involving countries that have liberalized most of their trade before signing an agreement will receive a higher score than will trade agreements involving countries with less liberalized trade, even if the agreement itself makes the same proportion of lines with a nonzero tariff duty-free. However, the trade agreement may, in effect, bind duty-free lines to 0 percent, suggesting that it is appropriate to include the duty-free lines in our measure. We expect that countries that sign trade agreements that provide for higher levels of tariff reductions will enjoy greater expansion of trade through the agreement.

Administration. The last category of our coding scheme focuses on the administrative aspects of the agreement: whether the agreement needs to be ratified, how amendments to the agreement are accepted, and how agreements are renewed. A trade agreement will be more credible the more pub- 
lic legitimacy it has, so we code a trade agreement that requires acceptance at the domestic level as stronger than one that goes into effect immediately after it is signed. An agreement that has to be renewed occasionally will not tie the hands of a government as much as one that goes on in perpetuity, because changes in domestic circumstances may alter political opinion on the desirability of the agreement and politicians have an easy way out of the agreement. Traders will also not be as confident that the government will keep its promise to abide by the agreement, so the agreement will have less credibility. Finally, agreements that have clauses indicating that amendments have to be ratified by all parties are considered more credible than agreements that do not mention the amendment process or allow countries to amend the agreement by simple agreement. ${ }^{7}$ Thus we expect trade agreements that provide for domestic ratification and those that require unanimity among members in amending the agreement to have a positive impact on trade liberalization and those that require renewals to have a negative effect on trade liberalization.

\section{Reciprocal Trade Agreements in Asia}

As of January 2011, the Asian Development Bank had reported 238 reciprocal trade agreements in the region that were under implementation, signed, under negotiation, or under consideration (http://aric.adb.org/1.php, accessed June 1, 2011). The rapid spread of trade agreements raises the question of how these agreements are likely to affect efforts toward multilateral trade liberalization. The active pursuit of trade agreements by emerging leading economies such as China and India, both developing countries, has led to concerns that such agreements, should they invoke the Enabling Clause of the WTO that allows developing countries to institute preferential trading schemes, would lead to more discriminatory trade practices and thus reverse the course toward multilateral trade liberalization. In addition, as John Ravenhill (2003) has pointed out, trade agreements in Asia are currently being formed among countries that are not significant trading partners, and no trade agreements are currently in the process of formation among larger trading nations such as China, Japan, and Korea. These trade agreements, therefore, may be largely symbolic in nature and function as little more than paper tigers.

Thus, it is especially important to evaluate the qualitative aspects of RTAs in Asia to understand their impact on trade flows and the likely course of trade liberalization among countries in the region. In this article, we analyze fifty-seven of the sixty-four agreements that were in effect as of 2006 and for which the agreement texts were available. Based 
on the coding scheme described in the previous section, the analysis identifies the agreements most likely to contribute to trade liberalization in Asia and beyond and distinguishes them from the paper tigers. In doing so, the analysis provides a means for developing a set of best practices for designing trade agreements that are likely to be the most successful for boosting trade among participants.

The Asian region also provides a varied set of cases on which to test our hypothesis that stronger credible commitment in trade agreements leads to higher trade flows. The Asian region includes more of a range of countries at different levels of development than any other region. Countries vary from the very poor (Burma, Bhutan) to the very well-off (Japan, Korea), and countries across the entire range have signed RTAs. Finally, focusing on Asia, where most of the RTAs have been signed in recent years, allowed us greater opportunity to fine-tune the coding scheme. Since the late 1980 s, and especially since the formation of the WTO, RTAs have become relatively standardized in terms of the areas covered. This similarity has required us to make finer distinctions within the different components than originally envisioned in order to reflect variations in credible commitment.

\section{Credible Commitment Scores in Asia's RTAs}

Table 1 lists alphabetically the fifty-seven RTAs that are included in our analysis, including the year in which the RTA was signed, when it went into force (if applicable), and its combined "score" on the nineteen components. ${ }^{8}$ Appendix 2 also provides correlation matrices between the categories as well as between individual components within categories. Because it is difficult to get an idea of patterns from looking at the raw data, we provide descriptive statistics of the commitment index in Table 2 , broken down by several factors.

Timing. The vast majority of RTAs in Asia were signed after 1995. Of the fifty-seven agreements that we coded, eleven were signed before 1995 and forty-six later. In fact, forty-five of these forty-six were signed in 2000 or later, and recent RTAs have much higher credibility scores than older ones. The average credibility score of agreements after 1995 is 0.669 , about double the pre-1995 average score of 0.353 . Part of the reason for the higher scores is that post-1995 agreements are more standardized and more likely to cover several key areas using similar language. For example, the WTO adopted agreements on technical barriers to trade and on escape clauses, so all agreements signed by WTO members pay at least lip service to these agreements. 
Table 1 Credible Commitment Scores of Asian RTAs

\begin{tabular}{|c|c|c|c|}
\hline Agreement & Signed & In Force & Credibility \\
\hline ASEAN Free Trade Area & 1992 & 1992 & 0.355 \\
\hline ASEAN Preferential Trade Agreement & 1977 & 1977 & 0.337 \\
\hline \multicolumn{4}{|l|}{ ASEAN-China Economic Cooperation } \\
\hline Agreement & 2004 & 2005 & 0.648 \\
\hline \multicolumn{4}{|l|}{ ASEAN-Korea Economic Cooperation } \\
\hline Agreement & 2005 & 2006 & 0.669 \\
\hline Australia-New Zealand Trade Agreement & 1965 & 1966 & 0.452 \\
\hline Bahrain-Thailand & 2002 & 2002 & 0.442 \\
\hline Bangkok Agreement & 1975 & 1976 & 0.530 \\
\hline Canada-Australia & 1960 & 1960 & 0.245 \\
\hline \multicolumn{4}{|l|}{ Economic Cooperation Organization Trade } \\
\hline Agreement & 2003 & & 0.626 \\
\hline European Free Trade Area-Singapore FTA & 2002 & 2003 & 0.840 \\
\hline India-Afghanistan PTA & 2003 & & 0.464 \\
\hline India-Chile PTA & 2006 & 2007 & 0.621 \\
\hline India-Mercosur PTA & 2004 & & 0.577 \\
\hline \multicolumn{4}{|l|}{ India-Singapore Economic Cooperation } \\
\hline Agreement & 2005 & 2005 & 0.560 \\
\hline India-Sri Lanka FTA & 1998 & 2001 & 0.588 \\
\hline Indo-Nepal Treaty of Trade & 1991 & 1991 & 0.236 \\
\hline Japan-Brunei FTA & 2007 & 2008 & 0.715 \\
\hline Japan-Chile EPA & 2007 & 2007 & 0.764 \\
\hline Japan-Indonesia EPA & 2007 & 2008 & 0.727 \\
\hline Japan-Malaysia EPA & 2005 & 2006 & 0.722 \\
\hline Japan-Mexico EPA & 2004 & 2005 & 0.748 \\
\hline Japan-Philippines EPA & 2006 & & 0.776 \\
\hline Japan-Singapore Economic Agreement & 2002 & 2002 & 0.747 \\
\hline Japan-Thailand EPA & 2007 & 2007 & 0.710 \\
\hline Korea-Chile FTA & 2003 & 2004 & 0.789 \\
\hline Korea-European Free Trade Area FTA & 2005 & 2006 & 0.746 \\
\hline Korea-Singapore FTA & 2005 & 2006 & 0.747 \\
\hline Korea-United States FTA & 2007 & & 0.795 \\
\hline Laos-Thailand PTA & 1991 & 1991 & 0.211 \\
\hline Malaysia-Pakistan Closer EPA & 2005 & 2008 & 0.759 \\
\hline Melanesian Spearhead Group & 1993 & 1993 & 0.456 \\
\hline New Zealand-China FTA & 2008 & 2008 & 0.799 \\
\hline New Zealand-Singapore Closer EPA & 2000 & 2001 & 0.741 \\
\hline Pacific Island Countries Trade Agreement & 2001 & 2003 & 0.543 \\
\hline Pakistan-Iran PTA & 2004 & 2006 & 0.552 \\
\hline Pakistan-Mauritius PTA & 2007 & 2007 & 0.425 \\
\hline Pakistan-Sri Lanka FTA & 2002 & 2005 & 0.657 \\
\hline
\end{tabular}


Table 1 continued

\begin{tabular}{|c|c|c|c|}
\hline Agreement & Signed & In Force & Credibility \\
\hline \multicolumn{4}{|l|}{ Papua New Guinea-Australia Trade } \\
\hline and Commercial Region & 1976 & 1977 & 0.498 \\
\hline People's Republic of China-Chile FTA & 2005 & 2006 & 0.696 \\
\hline \multicolumn{4}{|l|}{ People's Republic of China-Hong Kong } \\
\hline Closer EPA & 2003 & 2004 & 0.394 \\
\hline \multicolumn{4}{|l|}{ People's Republic of China-Macao } \\
\hline Closer EPA & 2003 & 2004 & 0.394 \\
\hline People's Republic of China-Pakistan FTA & 2006 & 2007 & 0.666 \\
\hline PTA-Group of Eight Developing Countries & 2006 & & 0.473 \\
\hline Singapore-Australia FTA & 2003 & 2003 & 0.732 \\
\hline Singapore-Jordan FTA & 2004 & 2005 & 0.719 \\
\hline Singapore-Panama FTA & 2006 & 2006 & 0.685 \\
\hline South Asian Free Trade Area & 2004 & 2006 & 0.613 \\
\hline South Asian Preferential Trade Area & 1993 & 1995 & 0.372 \\
\hline Taipei, China, and Guatemala FTA & 2005 & 2006 & 0.670 \\
\hline Taipei, China, and Nicaragua FTA & 2006 & 2008 & 0.709 \\
\hline Taipei, China, and Panama FTA & 2003 & 2004 & 0.833 \\
\hline Thailand-Australia FTA & 2004 & 2005 & 0.723 \\
\hline Thailand-New Zealand Closer EPA & 2005 & 2005 & 0.723 \\
\hline \multicolumn{4}{|l|}{ Trade Expansion and Cooperation } \\
\hline Agreement & 2005 & 2006 & 0.786 \\
\hline Trans-Pacific Strategic EPA & 1967 & 1968 & 0.191 \\
\hline United States-Australia FTA & 2004 & 2005 & 0.755 \\
\hline United States-Singapore FTA & 2003 & 2004 & 0.716 \\
\hline
\end{tabular}

Note $:$ FTA = free trade agreement; PTA = preferential trade agreement EPA = economic partnership agreement. Agreements missing a date had not gone into force when data were collected. The Japan-Philippines EPA went into force December 2008 and India-Mercosur PTA in June 2009.

PTAs vs. FTAs. In Asia, all agreements are either preferential trade agreements (PTAs), in which countries grant trade concessions to other signees but trade is not completely liberalized, or free trade agreements (FTAs), in which a substantial amount of trade is free from trade restrictions. There are currently no cases of customs unions, common markets, or economic unions. For the credibility score to have any meaning, PTAs should have, on average, lower scores than FTAs. Consistent with this expectation, the seventeen PTAs in the database have an average score of 0.431 , as contrasted with 0.684 for the forty FTAs. 
Table 2 Credible Commitment Scores by Category

\begin{tabular}{lcc}
\hline & Number & Average Credibility \\
\hline Year & & \\
$\quad$ Signed before 1995 & 11 & 0.353 \\
Signed after 1995 & 46 & 0.669 \\
Level & & \\
PTA & 17 & 0.431 \\
FTA & 40 & 0.684 \\
Members & & \\
Bilateral & 41 & 0.632 \\
Multilateral & 11 & 0.480 \\
Hub and spokes & 5 & 0.696 \\
\hline
\end{tabular}

Note $:$ PTA $=$ preferential trade agreement; FTA $=$ free trade agreement.

Multilateral vs bilateral agreements. Multilateral agreements tend to have lower scores than bilateral agreements, mainly because many of the multilateral agreements were signed before 1995 while few bilateral ones were signed before that year. Of the eleven multilateral RTAs in Asia, six were signed before 1995; the average credibility score of multilateral RTAs is 0.480 . In comparison, of the forty-one bilateral RTAs, only five were signed before $1995 .{ }^{9}$ The average score of the bilateral RTAs is 0.632 . A second difference between bilateral and multilateral agreements, though a relatively minor one given its weight, is that the latter have a mix of more developed and less developed countries in Asia, so the agreements have different liberalization schedules for the two types of countries. Also, the presence of more countries in the multilateral negotiations may mean that more interests are represented at the table. Because the agreement of all of the parties will be needed before the agreement is signed, each of the parties could act as a veto player (Tsebelis 1995). The threat that countries may hold up the agreement if there are unacceptable parts may lead to logrolling as sections that concern one or two parties are watered down at their request. Overall, the provisions acceptable to all parties in a multilateral agreement may be weaker than those in a bilateral one.

\section{Quantitative Analysis}

We employ directed-dyad data to examine whether our measure of RTA credibility has an effect on bilateral trade. Because the focus of this article 
is on Asian RTAs, we limit the observations to dyads containing at least one Asian country. In the case of South Korea, for example, we include trade between Korea and all of its trading partners, including Chile, with whom it signed an RTA in 2003, but there are no dyads between Chile and any non-Asian countries. The analysis examines the years 1970-2006. Asian countries did not start signing RTAs until the mid-1970s; even then they were relatively rare until the 1990 s. $^{10}$ Table 3 lists the Asian countries in the sample.

To test our hypothesis on the effects of credible commitment of RTAs on trade flows, we utilize the standard gravity model of international trade and estimate two sets of models. In the first set of models, we include a dummy variable for RTAs to examine whether the mere presence of an in-force RTA is sufficient to increase trade. In the second set of models, we replace the dichotomous RTA variable with our continuous measure of RTA credibility. If the dichotomous variable is significant and the continuous measure is not, it suggests either that a credible commitment is not necessary to affect trade or that our measure is not valid. If the dichotomous variable is not significant but the continuous measure is, it would suggest that there is a credible commitment element to RTAs. If both are significant, it could mean that some type of RTA is better than no RTA but more credible ones increase trade more.

Dependent variable. The dependent variable is the logged value of goods (in constant 2000 US dollars) imported into country 1 from country 2. The main source for the data is the International Montary Fund's Direction of Trade statistics. Missing data were filled in, when possible, with import data from Kristian Gleditsch (2002) ${ }^{11}$ Data from both sources

\section{Table 3 Asian Countries in the Quantitative Analysis}

\begin{tabular}{lll}
\hline Australia & Kiribati & Philippines \\
Bangladesh & Laos & Samoa \\
Bhutan & Malaysia & Singapore \\
Brunei & Maldives & Solomon Islands \\
Cambodia & Marshall Islands & South Korea \\
China & Mongolia & Sri Lanka \\
East Timor & Myanmar & Taiwan \\
Federated States & Nauru & Thailand \\
of Micronesia & Nepal & Tonga \\
Fiji & New Zealand & Tuvalu \\
India & Pakistan & Vanuatu \\
Indonesia & Palau & Vietnam \\
Japan & Papua New Guinea & \\
\hline
\end{tabular}


were converted into constant US dollars (year 2000) using the United States gross domestic product (GDP) deflator from the World Bank's World Development Indicators (WDI).

Independent variables. To control for economic conditions-economic size and the level of economic development-gravity models include controls for the logged products of both a dyad's GDP as well as its GDP per capita. Data on GDP and GDP per capita (both in constant 2000 US dollars) are from the World Bank's WDI. Our measure of currency unions is from Andrew Rose, with some modifications based on Benjamin Cohen to bring it up to date (Rose 2004; Cohen 2006). We include a dummy variable that equals 1 if both dyad members are in the General Agreement on Tariffs and Trade (GATT)/WTO. A second dummy variable takes on the value of 1 if only one of the two dyad members is in the GATT/WTO. The variables were constructed using the lists of GATT and WTO membership dates available from the WTO website (www.wto.org/ english/thewto_e/gattmem_e.htm and www.wto.org/english/thewto_e/ whatis_e/tif_e/org6_e.htm, respectively). As the analysis also includes year and dyadic fixed effects, many of the variables common in gravity models drop out of the model. These include land size, contiguity, the number of islands in the dyad, the number of landlocked countries in the dyad, colonies, and distance.

\section{Findings}

Existing studies-for example, by Andrew Rose $(2004,104)$ and Judith Goldstein, Douglas Rivers, and Michael Tomz (2007, 53-54)—generally find that RTAs have a positive effect on trade within a dyad. The coefficient on reciprocal RTAs in Goldstein, Rivers, and Tomz (2007, 53), for example, is 0.33 , which translates to a 42 percent increase in trade after an RTA goes into force for their 1946-2003 sample period. In the first column of Table 4, we attempt to replicate these findings by adding a dichotomous variable that takes on the value of 1 if there is an RTA in force within the dyad. This measure does not distinguish between RTAs, treating them all equivalently. All models in the article include both year and dyadic fixed effects, as that seems to be the standard now. In general, the control variables are as expected. GDP and GDP per capita are both positive and significant. Dyadic membership in a customs union also increases trade. Both of the GATT variables are negative but neither is significant.

Surprisingly, the RTA dummy variable, while positive, is not significant. Unlike other studies, we find that RTAs do not significantly increase 
Table 4 Regression Results, 1970-2006

\begin{tabular}{lcc}
\hline & $(1)$ & $(2)$ \\
& $\mathrm{b} / \mathrm{se}$ & $\mathrm{b} / \mathrm{se}$ \\
\hline RTA dummy & 0.145 & \\
Credibility index & $(0.090)$ & 0.224 \\
& & $(0.168)$ \\
GDP & $0.777^{* * *}$ & $0.779^{* * *}$ \\
GDP per capita & $(0.083)$ & $(0.083)$ \\
& $0.522^{* * *}$ & $0.521^{* * *}$ \\
Both GATT & $(0.079)$ & $(0.079)$ \\
& -0.0661 & -0.0651 \\
One GATT & $(0.063)$ & $(0.063)$ \\
Currency union & -0.0732 & -0.0724 \\
Constant & $(0.057)$ & $0.057)$ \\
& $0.911^{* *}$ & $0.911^{* *}$ \\
$N$ & $(0.390)$ & $(0.390)$ \\
Number of clusters & $-43.85 * * *$ & $(2.961)$ \\
\end{tabular}

Note: All models contain year and dyadic fixed effects. Significance levels: *.10, ${ }^{* *} .05,{ }^{* * *} .01$.

trade. Perhaps our measure of the credibility of RTAs will perform better. In the second column of Table 4, we present results using the composite credibility measure. Our variable is not significant, although like the RTA dummy variable, it is in the correct direction. These results are puzzling, especially because Goldstein, Rivers, and Tomz (2007, 62-63) find that the effect of RTAs is increasing over time. Why does the RTA variable have no effect in our sample, given its saliency in other work ${ }^{12}$ We further investigate this finding by disaggregating the credibility index and examining the effects of the individual categories and components.

\section{Unpacking the Index}

To determine whether some of the categories of our credibility index have more of an effect than others, we include each category individually in the model. The results are presented in Table 5. Three of the RTA credibility categories fail to reach significance. Both the type of RTA and the breadth of the RTA provisions, however, have a positive and significant effect on trade. ${ }^{13}$ The highest level of RTA in Asia is a free trade 
agreement. Moving from no RTA or a preferential agreement to a free trade agreement increases trade by 25 percent. ${ }^{14}$ If we include separate dummy variables for a preferential agreement and a free trade agreement, the latter is statistically significant while the former is not. Not surprisingly, this suggests that minimal agreements where countries liberalize trade only on some products do not have a large effect on trade, whereas promises to liberalize substantially all products do have an effect.

The breadth of coverage measure ranges from 0 to a maximum of .932. Increasing the value of this measure from 0 to the median value of .532 (for observations with an RTA) increases trade by 21 percent, while trade increases by 41 percent if breadth moves from 0 to the maximum.

Table 5 Credibility Categories, 1970-2006

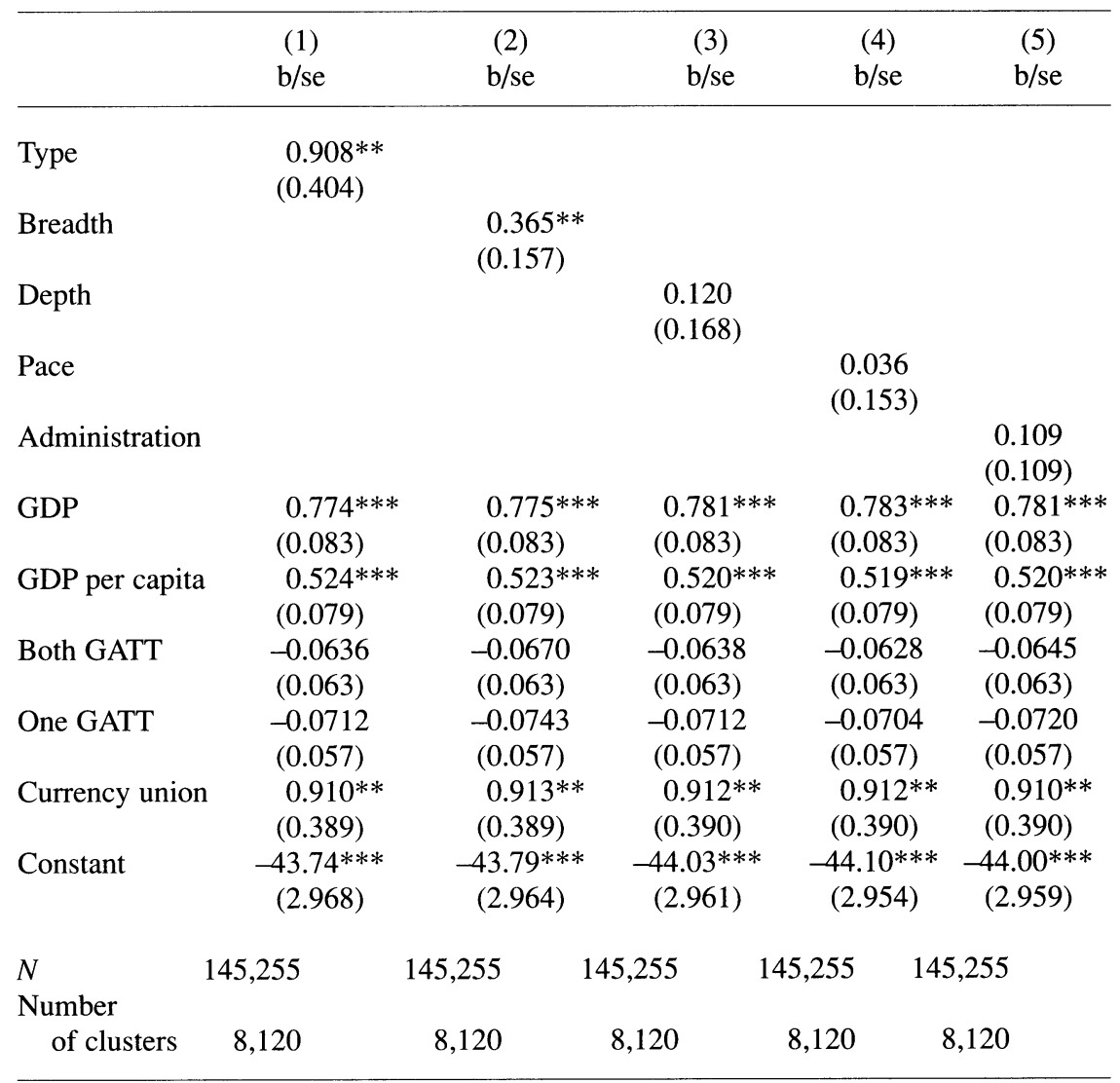

Note: All models contain year and dyadic fixed effects. Significance levels: *.10, **.05, ***.01. 
As discussed previously, the components in this category focus on the range of products covered and the treatment of nontariff trade restrictions. As was the case for the type of agreement category, the results here suggest that the more products covered by the agreement and the more an agreement attempts to liberalize trade restrictions, the stronger is the effect on trade expansion.

Surprisingly, the depth of coverage category-which includes the dispute settlement mechanism clauses and the escape clauses-is insignificant. Perhaps there are too many components for the dispute settlement and escape clauses to show an effect. In the following paragraphs we present the analysis of individual components, focusing on the breadth of coverage category. The results are presented in Table 6 . We also compare the results when the dispute settlement clauses or escape clauses are mentioned.

The breadth of coverage category, as detailed in Appendix 1, includes five individual components: (1) whether tariff concessions are reciprocal; (2) whether the agreement covers industrial products; (3) whether the agreement covers agricultural products; (4) whether the agreement covers nontariff barriers to trade; and (5) how stringent are restrictions on technical barriers to trade. In Table 6, we substitute each of the individual components in the breadth of coverage category for the RTA measure in order to assess their separate effects on trade flows. The coverage of nontariff barriers (NTBS) has a marginally significant effect on trade flows but the effect of technical barriers to trade (TBTS) is statistically insignificant. However, whether the tariff concessions negotiated are reciprocal (Reciprocal) and whether the agreement covers industrial (Industrial Goods) and/or agricultural goods (Agriculture), all have a positive and statistically significant effect on trade flows.

These three individual components all contribute strongly to the trade-creating effect of an RTA. In terms of substantive effects that arise from the absence of an RTA to the highest value on an individual component, RTAs with reciprocal reductions that are implemented within the same time frame by agreement partners results in a 25.4 percent increase in trade. Agreements that cover more than 80 percent of industrial goods-the highest category for coverage of industrial goods-are associated with a 29.4 percent increase in trade. Finally, RTAs with provisions that cover more than 80 percent of agricultural goods-also the highest category of coverage for agricultural products-are associated with a 30.9 percent increase in trade. Overall, then, what appears to be important in increasing trade is product coverage. The more products that are covered by the agreement, the greater the increase in trade. 
Table 6 Breadth of Coverage Components, 1970-2006

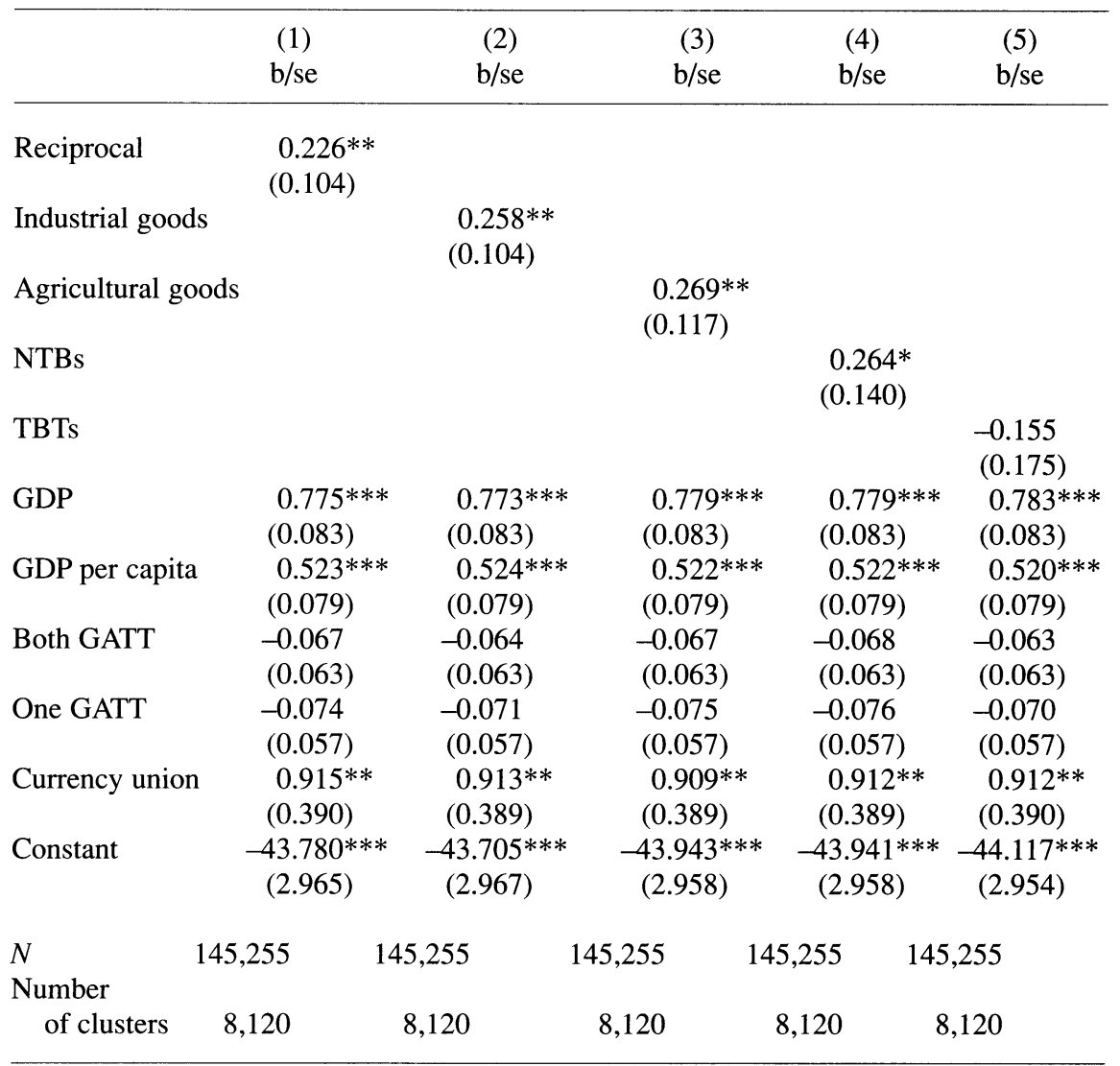

Note: All models contain year and dyadic fixed effects. Significance levels: *.10, **.05, ***.01.

Few of the other components have a significant effect on trade. The formalization of the dispute settlement mechanism does have a significant effect on trade, but neither how binding the dispute settlement resolution is nor the compensation for losing a dispute settlement case is significant. Escape clause provisions are also not significant. These findings could suggest that some flexibility in the agreement is necessary to relieve domestic pressure, but more work needs to be done.

Finally, the extent of the tariff cuts, or the percentage of tariff lines that are 0 percent when the agreement goes into effect, has a significant but negative effect on trade. Eliminating a higher proportion of tariffs right away actually decreases trade. This may reflect in part the fact that in many 
of the agreements that eliminate tariffs from the outset, at least one of the countries already imposes few tariffs (e.g., Singapore). Nevertheless, the negative coefficient suggests that an elimination of tariff lines over time may have more of an impact than a large immediate elimination.

\section{Conclusion}

In this article, we have argued that although RTAs can be seen as credible commitments to liberalize trade, not all RTAs encode the same level of credible commitment in their provisions. Some agreements are weaker than others in providing for the liberalization of trade, as they allow for trade-distorting measures or provide subjective dispute settlement mechanisms that frustrate trade. In developing this argument, we constructed a coding scheme to measure RTA credibility based on the RTAs' legal texts and applied it to agreements involving at least one Asian country. In our analyses of RTAs in Asia and their impact on trade flows for the years 1970-2006, we find that neither our credibility measure nor a dichotomous RTA measure has a significant effect on trade. To dissect this finding, we focused on the individual components of the agreements. We find that some aspects of the agreement are associated with increased trade, especially those that provide for liberalization for a wider range of products and for a formal dispute settlement process. This set of results may well reflect the distinguishing features of Asia's RTA landscape and calls for future research that compares Asia's economic governance with other regions and more broadly with global trends.

With the veritable explosion of RTAs signed in Asia, some scholars have argued that RTAs are no longer primarily about trade; instead, RTAs are now signed for other economic reasons or for political purposes. ${ }^{15}$ RTAs increasingly include investment provisions, reflecting the dominance of intra-industry trade and the equally pressing need to resolve commitment problems surrounding foreign direct investment. Politically, RTAs may serve as a useful scapegoat to bolster domestic economic reform in uncompetitive sectors (Pempel and Urata 2006), to promote the United States' foreign policy agenda of rewarding economic reform and securing allies (Feinberg 2006), or as a means of strategic engagement of neighboring states, as has been argued for China's free trade agreement with the ASEAN countries (Kwei 2006). In such cases, and as RTAs become more commonplace in the region, we would expect that RTAs should gradually have less effect on trade. We find that under certain conditions, certain institutional provisions of RTAs are still strongly associated with increased trade. In future work, we hope to investigate fur- 
ther the effect of both time and space as more trade data become available and as we apply our index to RTAs in other areas of the world.

Raymond Hicks is the statistical programmer at the Niehaus Center for Globalization and Governance, Woodrow Wilson School of Public and International Affairs, Princeton University. His main research area is international political economy, with a specialization in monetary and trade politics. His current research projects focus on the WTO and international trade, foreign aid and development, and the politics of trade agreements.

Soo Yeon Kim is associate professor of political science at the National University of Singapore. She is the author of Power and the Governance of Global Trade: From the GATT to the WTO (2010). Her research specialization is the politics of trade, and her current research program includes projects on institution building and the politics of trade agreements in post-Cold War Asia, compliance in WTO disputes, and rising powers in the global economy.

\section{Appendix 1 RTA Coding Scheme}

Type of RTA: Proposed level of integration

$0 \quad$ Preferential trade agreement

.25 Free trade agreement

.5 Customs union

.75 Common market

1 Economic union

Breadth of coverage: Coverage of products and standards other than trade. For the products covered and the timetable of reductions, the more stringent reductions are coded.

Reciprocal: Are the tariff reductions reciprocal?

0 Concessions by only one party

.5 Concessions by both, but different time frames

1 Reciprocal reductions

Industry: Does the agreement cover industrial products?

$0 \quad$ No or very few industrial products covered $(<10 \%)$

.5 Some industrial products covered $(20-80 \%)$

1 All industrial products covered ( $>80 \%)$

Agriculture: Does the agreement cover agricultural products?

$0 \quad$ No or very few agricultural products covered $(<10 \%)$

.33 Some processed agricultural products covered (20-80\%)

.66 Some raw agricultural products covered $(20-80 \%)$

1 All agricultural products covered $(>80 \%)$

$N T B$ : Does the agreement cover nontariff barrier restrictions on trade?

$0 \quad$ No mention

.33 Quantitative restrictions eliminated more slowly than tariffs

.66 Eliminated at same pace or more quickly, but exclusions allowed

1 Eliminated at same pace or more quickly than tariffs and no exclusions 


\section{Appendix 1 continued}

Techbarrier: How stringent are restrictions on technical barriers to trade?

$0 \quad$ Not covered

.25 Barriers not to restrict trade

.5 Cooperation on standards

.75 Standards must be objective, with some exceptions allowed

1 Standards must be objective, with no exceptions

Depth of coverage: Strength of RTA provisions

Dispute settlement: How are disputes between the parties settled?

$0 \quad$ No dispute settlement mentioned

.5 Informal consultations between the parties

1 Formal process in place

Resolution: In case of disputes, how binding is the resolution?

$0 \quad$ Not mentioned

.33 Resolution is suggestive but not binding

.66 Resolution binding but can be appealed

1 Resolution binding and cannot be appealed

Compensation: When compensation is decided, how is the amount determined?

$0 \quad$ Not mentioned

.33 At discretion of contracting party with no standard

.66 At discretion of contracting party with specific guidelines

1 At discretion of formal arbiters

Escape clause (EC) identification: How are import surges identified?

$0 \quad$ Countries identify import surges

.33 Consultations between parties with no settlement mechanism

.66 Based on objective criteria (WTO guidelines)/consultation with settlement mechanism (non-WTO)

1 Stricter standards than WTO/specific guidelines (before WTO)

$E C$ action: If protection from import surges is required, how is the level

decided? (WTO agreement has four-year limit and compensation)

0 No mention

.25 Suspension of tariff concessions on surge product

.5 Suspension of concessions with specific time limit $(<=2$ years)

.75 Suspension of concessions with compensation to other party

1 Suspension of concessions with compensation and time limit

Dumping clauses: Stringency of antidumping clause

0 No antidumping clause/antidumping clause to be established

.33 Determination of dumping up to party

.66 (After 1995) WTO clause/(before 1995) joint consultations to determine whether dumping occurred with possibility of outside mediation

1 (After 1995) Antidumping clause more stringent than WTO clause/(before 1995) clause contains specific guidelines for determine dumping

Formal institutions: Does the agreement create formal institutions?

$0 \quad$ No formal institutions

.5 Formal institutions with suggestion and recommendation powers

1 Formal institutions with decisionmaking power 


\section{Appendix 1 continued}

Meetings: How are meeting between the parties arranged?

$0 \quad$ No procedure for meetings

.33 Meetings only when requested by one of the contracting parties

.66 Meetings at least once a year

1 Meeting at least once a year or whenever requested by a contracting party

Pace of change: Pace of liberalization for RTA participants

Timetable: How long is the process to reach the final objective of the agreement?

$0 \quad$ No timetable

.25 Greater than or equal to 10 years

.50 Between 5 and 10 years

.75 Less than 5 years

1 Immediately

Extent: Percentage of tariff lines duty-free when agreement goes into force

$0 \quad 0 \%-9 \%$

$.1 \quad$ Between $10 \%$ and $19 \%$

$.2 \quad 20-29 \%$

$.3 \quad 30-39 \%$

$.4 \quad 40-49 \%$

$.5 \quad 50-59 \%$

$.6 \quad 60-69 \%$

$.7 \quad 70-79 \%$

$.8 \quad 80-89 \%$

$.9 \quad 90-99 \%$

$1 \quad$ All tariffs eliminated

\section{Administration}

Ratification: Does the agreement need to be ratified by the domestic legislature?

$0 \quad$ Agreement goes into force when signed

1 Agreement needs to be ratified by legislature

Renewal: Does the agreement have to be renewed?

0 After given number of years, parties have to agree to renewal

.5 After given number of years, automatically renewed unless one party opts out (automatic renewal)

1 Agreement is in force unless one party withdraws (no renewal necessary)

Amendment: What is the amendment process for the agreement?

$0 \quad$ No amendment process mentioned

.5 Amendments have to be agreed by all parties

1 Amendments have to go through domestic ratification process 


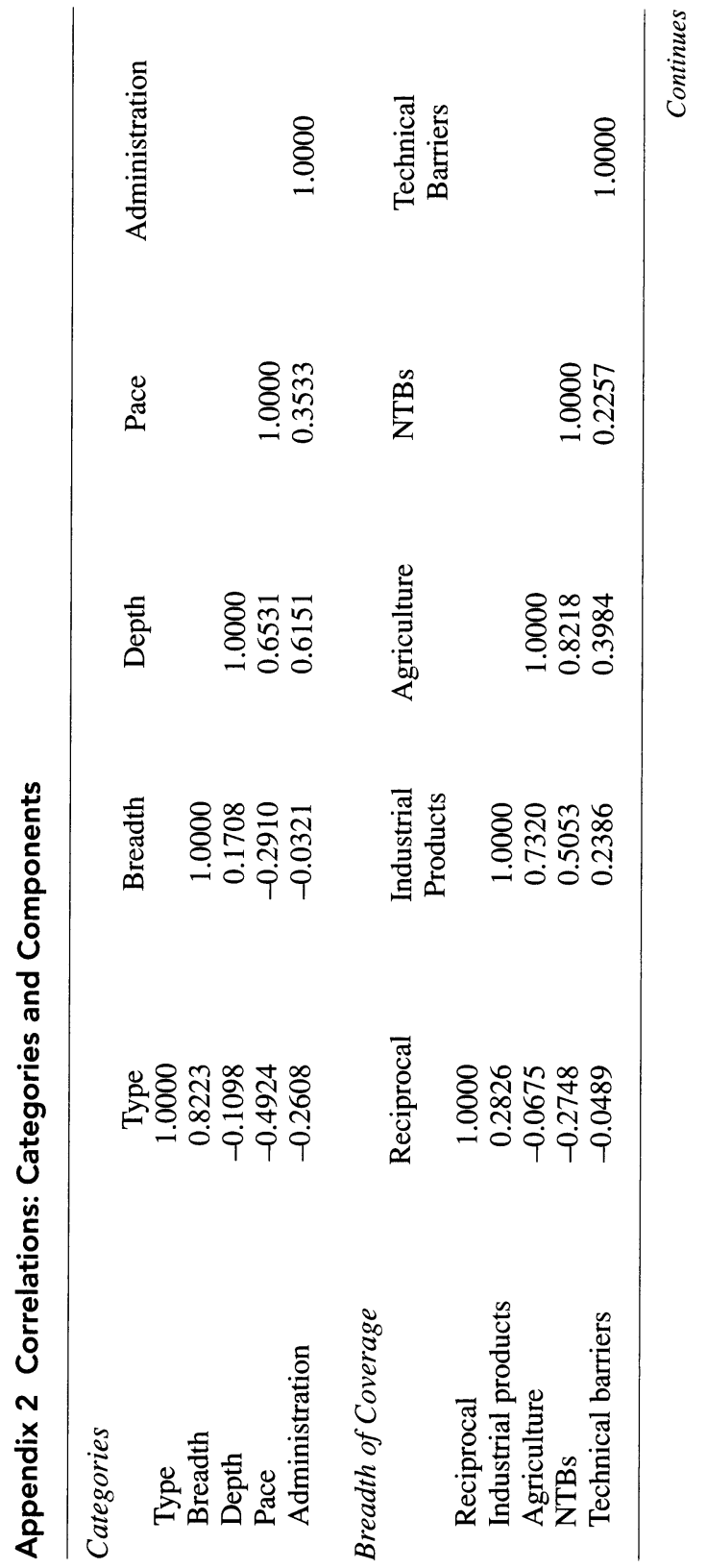




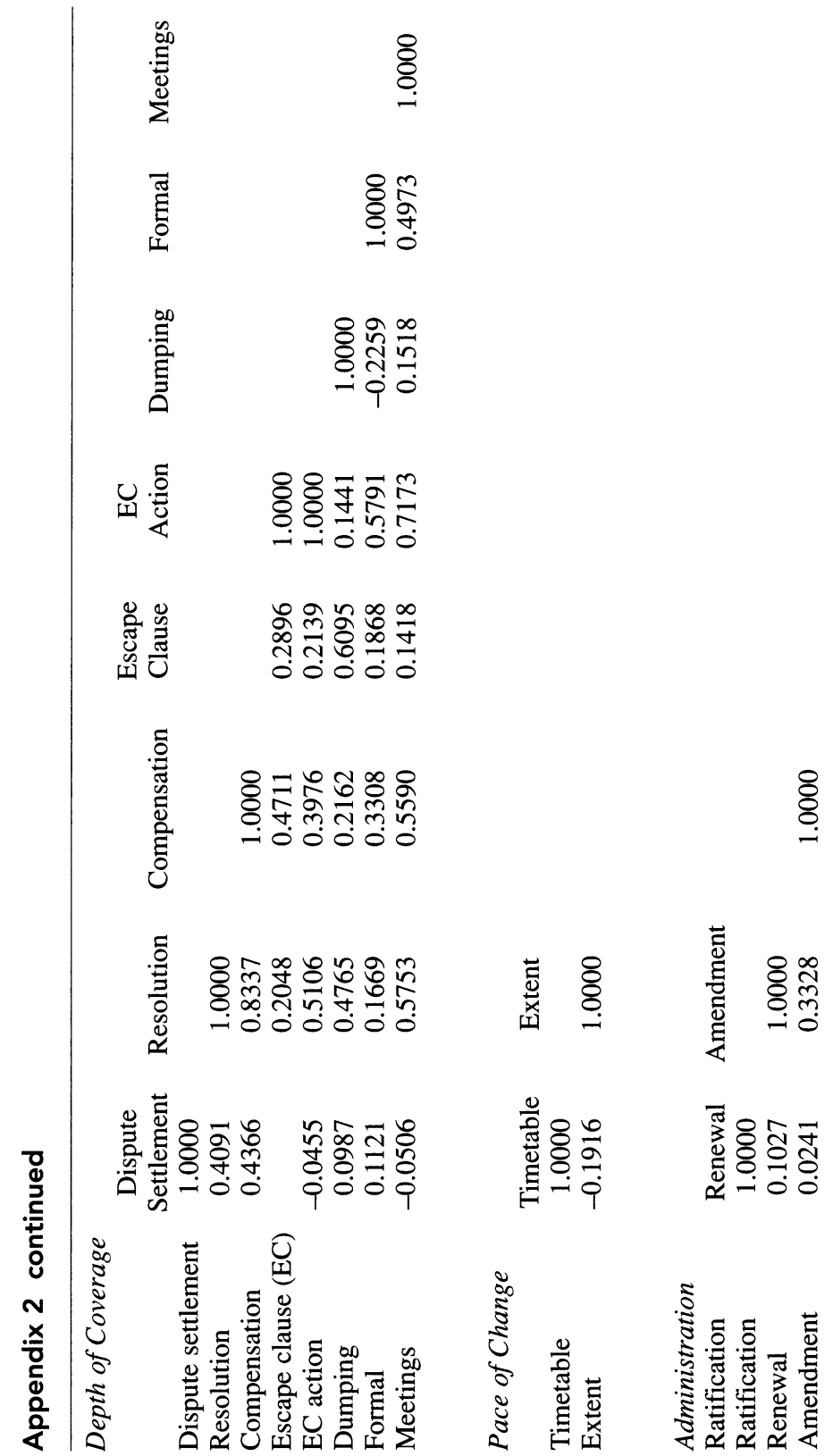




\section{Notes}

The authors are especially grateful to Joanne Gowa, Helen Milner, and Rob O'Reilly for comments and suggestions on earlier versions of this article. At the Journal of East Asian Studies, we received excellent feedback from Stephan Haggard and two anonymous reviewers. We also thank Thilo Bodenstein, Christina Davis, Yoram Haftel, Yuch Kono, Peter Rosendorff, and Dustin Tingley and acknowledge comments received at the annual meeting of the International Political Economy Society (2008), the International Studies Association (2009), and the Midwest Political Science Association (2009). Soo Yeon Kim gratefully acknowledges the support of fellowships from the East Asia Institute (Seoul, Korea) and the East-West Center (Washington, DC) in the preparation of this study.

1. The few trade agreements in force before the rapid surge of the mid-1990s include the Bangkok Agreement, in force since 1976, and the South Pacific Regional Trade and Economic Cooperation Agreement (SPARTECA), which was signed in 1981 and provided for nonreciprocal preferential trade for exports of South Pacific countries to Australia and New Zealand.

2. On the success of trade liberalization and economic integration through APEC, see, for example, Bora and Pangestu (1996) and Pangestu and Gooptu (2004).

3. This article excludes nonpreferential trade agreements such as the South Pacific Regional Trade and Economic Cooperation Agreement (SPARTECA).

4. The rationale for the coding applied to breadth of coverage is that an agreement that has different timetables for the participant countries may not be as credible as those that require the same timetables. Because the focus of this article is on reciprocal trade agreements, none of the agreements coded receive a score of 0 on this measure. There are differences in the timing of the tariff cuts that we felt were important but are restricted to a couple of cases. First, many multilateral trade agreements have different schedules for the lesser and more developed countries, so those were coded as .5. Also, Singapore basically has no tariff rates, so in its agreements it tends to eliminate all of its tariffs upon entry into force while allowing the partner country more latitude (with a couple of exceptions). These were also coded as .5.

5. We are grateful to Helen Milner for encouraging us to think more critically of our coding of flexibility provisions. The existing scholarship points to similar tensions in dispute settlement mechanisms, in the form of trade-offs between "rigidity and stability" as exemplified in the WTO's dispute settlement mechanism (Rosendorff 2005). Rosendorff argues that institutional mechanisms such as the WTO's Dispute Settlement Understanding allow temporary “defections" from obligations that render a more stable institution. Rosendorff also argues that this dilemma can be similarly mitigated through flexibility mechanisms such as escape clauses. Smith $(2000,143-150)$ refers to the dilemma between "treaty compliance" and "policy discretion," and argues that how domestic political actors assess the trade-offs between these two desirable goals determines the strength of legalism in dispute settlement mechanisms. From this point of view, an agreement 
will be more effective if governments are permitted to invoke escape clauses under specific conditions in order to alleviate pressures from domestic constituents.

6 . To receive a value greater than 0 on this measure, the agreement must specify that some tariff lines will be cut to 0 percent. In other words, there must be something in the agreement that binds the tariffs at 0 percent.

7. Here and in the ratification component, we consider ratification to be any requirement that the agreement or amendment has to be accepted through the domestic approval process.

8. The values indicate the unweighted combined scores across the nineteen components. We thank an anonymous reviewer's recommendation that we maintain the unweighted version, as the relative importance of the five categories is already reflected in the number of components each category comprises. In addition, not all agreements have information about every component in the index. Many of the components penalize an agreement for not having information; that is, they are coded as 0 if they lack detail about dispute settlement clauses. Other components that lack information (such as information about the timetable or the extent of tariff elimination) are coded as missing and are not included in the numerator or denominator of the category or index total. The category and index totals, therefore, are rescaled to include only those components about which there is information.

9. In addition, there are five cases of hub-and-spoke agreements, or agreements between an existing RTA (such as ASEAN) and another country. These agreements do not involve full membership or even association with the existing RTA. All of the hub and spoke agreements were signed after 1995, and their average credibility score is 0.696 (see Table 2).

10. ASEAN was formed in 1967, but a trade aspect was not added until the ASEAN Preferential Trade Agreement was signed in 1977. The Bangkok Agreement (1976) was the first RTA among Asian countries only.

11. Although Gleditsch makes some disputable assumptions about trade patterns to fill in missing data, he does have trade data for Taiwan, unlike the International Monetary Fund (IMF).

12. Preliminary analyses using the RTA dummy variable and the composite credibility index showed that the trade-creation effect of RTAs does obtain, but this effect is limited to the years 1970-2003. We also replicate our analysis on the Goldstein, Rivers, and Tomz (2007) data, after restricting their sample to dyads involving at least one Asian country and adding in our two RTA measures. The RTA variables were significant and in the correct direction. The results are available upon request. These preliminary findings suggest that there may be a strong time component to the trade effects of RTAs. As most of the Asian RTAs have been signed in the last few years, they may take some time to have an effect on trade, beyond the temporal scope of this study. They may also capture the standardization of recent RTAs that makes them less differentiable in their economic consequences. Finally, there simply may be more "paper tigers" in recent RTAs, as countries may not be signing RTAs in order to increase trade as much as they are signing them as a response to competitive pressures from the RTA projects of other countries or for political reasons rather than the economic benefits of such agreements. 
13. The type category codes preferential trade agreements as 0 , so in the analysis they are treated the same as no RTA. We reran the regression with type recoded so that preferential agreements receive a score of .2 and free trade agreements a score of .4 . The results do not change.

14. Percentage changes were calculated by $e^{\beta}-1$.

15. For example, Taiwan has tried to sign RTAs with all the countries in Central America to achieve more international legitimacy. They have succeeded in signing RTAs with Panama, Guatemala, Nicaragua and, most recently, Honduras and El Salvador. Costa Rica has turned them down.

\section{References}

Abbott, Kenneth W., Robert O. Keohane, Andrew Moravcsik, Anne-Marie Slaughter, and Duncan Snidal. 2000. "The Concept of Legalization." International Organization 54, 3: 17-35.

Bagwell, Kyle, and Robert W. Staiger. 1999. "An Economic Theory of GATT." American Economic Review 89: 215-248.

- 2002. The Economics of the World Trading System. Cambridge: MIT Press.

. 2010. "The WTO: Theory and Practice." Annual Review of Economics 2: 223-256.

Baier, Scott L., and Jeffrey H. Bergstrand. 2007. "Do Free Trade Agreements Actually Increase Members' International Trade?" Journal of International Economics 71, 1: 72-95.

Bora, Bijit, and Mari Pangestu, eds. 1996. Priority Issues in Trade and Investment Liberalisation: Implications for the Asia Pacific Region. Singapore: Pacific Economic Cooperation Council (PECC).

Brainard, S. L. 1994. "Last One Out Wins: Trade Policy in an International Exit Game." International Economic Review 35, 1: 151-172.

Carmichael, Callum M. 1987. "The Control of Export Credit Subsidies and Its Welfare Consequences." Journal of International Economics 23, 1-2: $1-19$.

Cohen, Benjamin J. 2006. The Future of Money. Princeton: Princeton University Press.

Cukierman, Alex, Steven B. Webb, and Bilin Neyapti. 1994. Measuring Central Bank Independence and Its Effect on Policy Outcomes. San Francisco: ICS Press.

Feinberg, Richard. 2006. "U.S. Trade Arrangements in the Asia-Pacific." In Bilateral Trade Agreements in the Asia-Pacific: Origins, Evolution, and Implications, ed. Vinod K. Aggarwal and Shujiro Urata. New York: Routledge.

Gleditsch, Kristian Skrede. 2002. "Expanded Trade and GDP Data." Journal of Conflict Resolution 46, 5: 712-724.

Goldstein, Judith L., Douglas Rivers, and Michael Tomz. 2007. "Institutions in International Relations: Understanding the Effects of the GATT and the WTO on World Trade." International Organization 61, 1: 37-67. 
Grilli, Vittorio, Donato Masciandaro, and Guido Tabellini. 1991. "Political and Monetary Institutions and Public Finance Policies in the Industrial Countries." Economic Policy 13: 341-392.

Grossman, Gene, and Elhanan Helpman. 1994. "Protection for Sale." American Economic Review 84, 4: 833-850.

- 1995. "The Politics of Free Trade Agreements." American Economic Review 85, 4: 667-690.

Kwei, Elaine S. 2006. "Chinese Trade Bilateralism: Politics Still in Command." In Bilateral Trade Agreements in the Asia-Pacific: Origins, Evolution, and Implications, ed. Vinod K. Aggarwal and Shujiro Urata. New York: Routledge.

Maggi, Giovanni, and Andrés Rodríguez-Clare. 1998. "The Value of Trade Agreements in the Presence of Political Pressures." Journal of Political Economy 106, 3: 574-601.

- 2007. "A Political-Economy Theory of Trade Agreements." American Economic Review 97, 4: 1374-1406.

Matsuyama, Kiminori. 1990. "Perfect Equilibria in a Trade Liberalization Game." American Economic Review 80, 3: 480-492.

Mitra, Devashish. 2002. "Endogenous Political Organization and the Value of Trade Agreements." Journal of International Economics 57, 2: 473-485.

North, Douglass, and Barry Weingast. 1989. "Constitutions and Commitment: The Evolution of Institutions Governing Public Choice in SeventeenthCentury England.” Journal of Economic History 44, 4: 803-832.

Pangestu, Mari, and Sudarshan Gooptu. 2004. "New Regionalism: Options for East Asia." In East Asia Integrates: A Trade Policy Agenda for Shared Growth, ed. Kathie Krumm and Homi Kharas. Washington, DC: World Bank and Oxford University Press.

Pempel, T. J., and Shujiro Urata. 2006. "Japan: A New Move Toward Bilateral Trade Agreements." In Bilateral Trade Agreements in the Asia-Pacific: Origins, Evolution, and Implications, ed. Vinod K. Aggarwal and Shujiro Urata. New York: Routledge.

Ravenhill, John. 2003. "The New Bilateralism in the Asia Pacific." Third World Quarterly 24, 2: 299-317.

. 2008a. "The Move To Preferential Trade on the Western Pacific Rim: Some Initial Conclusions." Australian Journal of International Affairs 62, 2: $129-150$.

- 2008b. "Trading Out of Crisis." In Crisis as Catalyst: Asia's Dynamic Political Economy, ed. Andrew MacIntyre, T. J. Pempel, and John Ravenhill, 140-163. Ithaca: Cornell University Press.

Rose, Andrew. 2004. "Do We Really Know That the WTO Increases Trade?" American Economic Review 94, 1: 98-114.

Rosendorff, B. Peter. 2005. "Stability and Rigidity: Politics and Design of the WTO's Dispute Settlement Procedure." American Political Science Review 99, 3: 389-400.

Rosendorff, B. Peter, and Helen V. Milner. 2001. "The Optimal Design of International Trade Institutions: Uncertainty and Escape." International Organization 55, 4: 829-857. 
Smith, James McCall. 2000. "The Politics of Dispute Settlement Design: Explaining Legalism in Regional Trade Pacts." International Organization 54, 1: $137-180$.

Staiger, Robert W., and Guido Tabellini. 1987. "Discretionary Trade Policy and Excessive Protection." American Economic Review 77, 5: 823-837.

Tsebelis, George. 1995. "Decision Making in Political Systems: Veto Players in Presidentialism, Parliamentarism, Multicameralism, and Multipartyism." British Journal of Political Science 25: 289-325. 


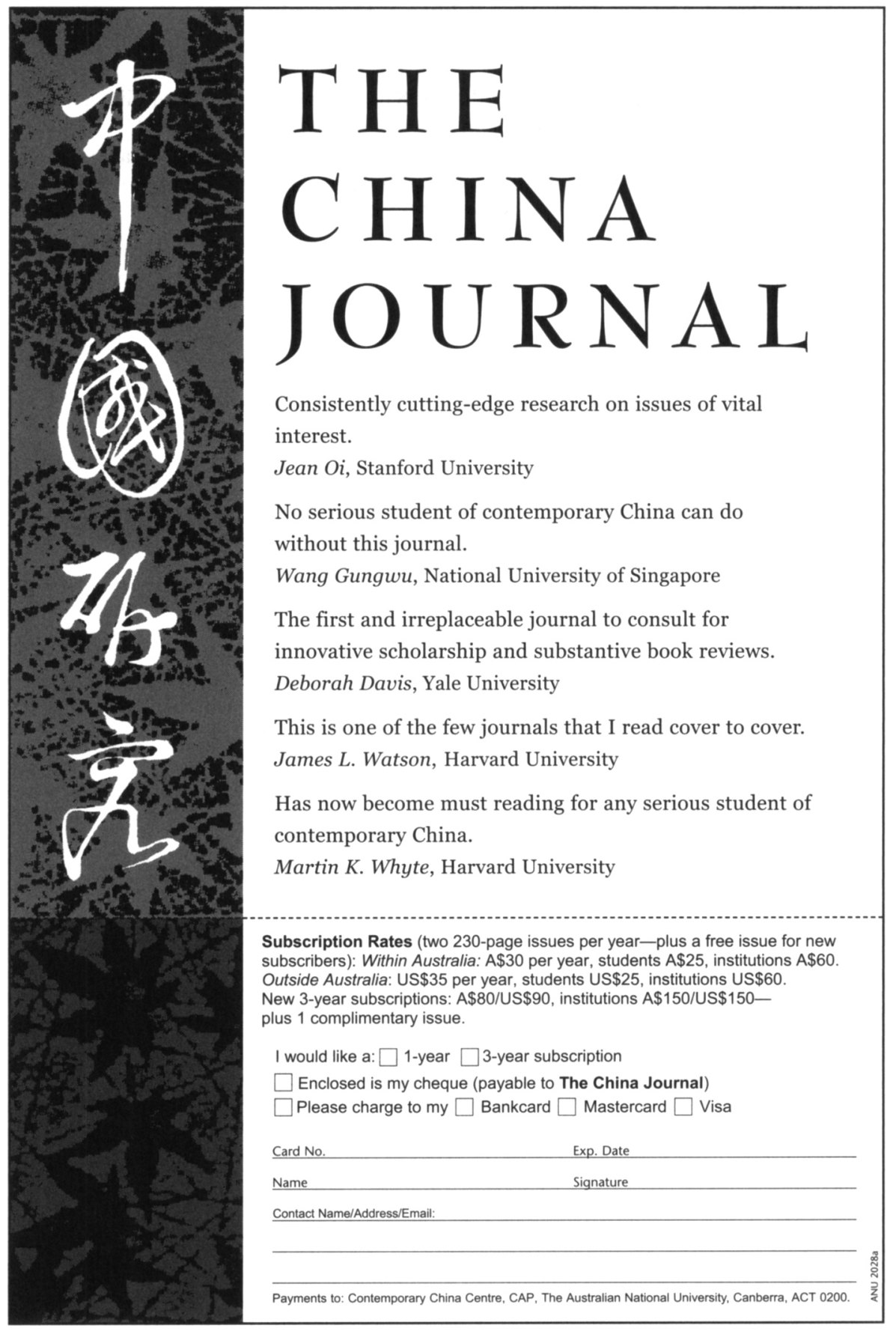

